We wish to thank Dr. B. Barling, of St. James' Hospital, Eondon, for permission to publish Cases 1 and 2, and Dr. Cecil Symons, of New End Hospital, London, for permission to publish Case 3. We are grateful for the advice and encouragement of Professor J. F. Goodwin in the preparation of this paper, especially in regard to Case 2, which was under his care at the Postgraduate Medical School, London.

REFERENCES

Beck, A. L. (1934). Laryngoscope, 44, 431.

Browse, N. (1964). Brit. med. F., 1, 669

Ciutti, A., and Skinner, E. F. (1955). f. thorac. Surg., 30, 143.
Dodd, H., and Cockett, F. B. (1956). The Pathology and Surgery of the Veins of the Lower Limb. Livingstone, Edinburgh.

Flett, R. L. (1941). Brit. med. f., 2, 223.

Frimann-Dahl, J. (1935). Acta chir. scand., 76, Suppl. No. 36.

Gilmore, G. B. (1939). Laryngoscope, 49, 106

Ormerod, J. A. (1889). Trans. path. Soc. Lond., 40, 75.

Payling Wright, H., and Osborn, S. B. (1952). Brit. Heart f., 14, 325

Schechter, M. M. (1954). Amer. F. med. Sci., 227, 46.

Sharnoff, J. G. (1959). F. Amer. med. Ass., 169, 688.

Sleight, P. (1962). Brit. Heart f., 24, 726.

Smith, A. B. (1950). F. Laryng., 64, 12.

Stone, F. E., and Berger, M. D. (1936). Arch. Otolaryng., 24, 141.

Wood, P. (1950). Brit. med. 7., 2, 639, 693.

- (1956). Diseases of the Heart and Circulation, 2nd ed., pp. 47-57, 320-321, 503. Eyre and Spottiswoode, London.

\title{
Reduction of "Rebound" Hypercoagulability by Gradual Withdrawal ("Tailing Off") of Oral Anticoagulants
}

\author{
L. POLLER,* M.D., M.C.PATH. ; JEAN M. THOMSON,† I.M.L.T.
}

Brit. med. F., 1965, 1, 1475-1476

There is a clinical impression that fresh thrombotic attacks are more likely to occur shortly after anticoagulant treatment is stopped. We have previously shown that there is " rebound" hypercoagulability in patients whose long-term anticoagulant treatment has been suddenly withdrawn (Poller and Thomson, 1964). An increase in both "extrinsic" and "intrinsic" systems of blood coagulation was found to be present one week after treatment was stopped, and this hypercoagulable state persisted for some time afterwards. Although the presence of abnormal coagulability is not synonymous with "rebound" thrombosis, it is obviously undesirable in a patient who has previously experienced a thrombotic episode. In this investigation we have studied the effect of gradual withdrawal of oral anticoagulants over a period of four weeks in a group of patients who had been on long-term therapy and compared the results obtained with a group of normal volunteers studied in parallel.

\section{Method of Study}

The discontinued group consisted of nine patients who had been on long-term therapy with nicoumalone (Sinthrome) for periods between 5 and 43 months, with a mean of 14 months. They were made up as follows: eight with myocardial infarction and one with thrombophlebitis.

The normal group consisted of seven healthy members of the staff of the department. Venepunctures were performed

- Consultant Haematologist, Withington Hospital, Manchester. † Research Technician, Withington Hospital, Manchester. on this group at the same intervals and on the same day as on the discontinued patients. This was to ensure the stability of the reagent and the reproducibility of the tests over the period of study. In addition, data were available for analysis from recent studies performed on 80 other normal subjects, using the same techniques and reagents. The following tests were performed both on patients and on controls at each visit: prothrombin activity (Quick test), Factor VII assay, heparin plasma clotting-time, cephalin time, antihaemophilic globulin (A.H.G. ; Factor VIII).

The techniques were precisely the same as those used in the previous investigation (Poller and Thomson, 1964). The " tailing off " period was of four weeks' duration. The dosage schedule was as follows: the original full dosage was halved for the first two weeks, and then after two weeks on the reduced schedule it was again halved for a further two weeksthat is, one-quarter the original dose. The treatment was then finally stopped.

\section{Results}

Detailed results obtained in both the discontinued and the normal groups are given in the Table. On the final day of their period of full-dosage anticoagulant treatment the discontinued group showed a significant reduction of prothrombin activity and Factor VII activity. There was no significant alteration of the cephalin time or heparin plasma clottingtimes. In contrast a significant increase in the concentration of Factor VIII was detected.

Table of Results

\begin{tabular}{|c|c|c|c|c|c|c|c|c|c|c|c|c|c|c|c|}
\hline \multirow{3}{*}{ Week } & \multirow{3}{*}{ Group } & \multirow{2}{*}{\multicolumn{2}{|c|}{ P.A. }} & \multirow{2}{*}{\multicolumn{2}{|c|}{ Factor VII Assay }} & \multirow{2}{*}{\multicolumn{2}{|c|}{ Cephalin Time }} & \multirow{2}{*}{\multicolumn{2}{|c|}{$\begin{array}{l}\text { Heparin } \\
\text { Clotting-time }\end{array}$}} & \multicolumn{6}{|c|}{ A.H.G. (Factor VIII) Assay } \\
\hline & & & & & & & & & & \multicolumn{2}{|c|}{$10 \%$} & \multicolumn{2}{|c|}{$20 \%$} & \multicolumn{2}{|c|}{$30 \%$} \\
\hline & & sec. & S.D. & sec. & S.D. & sec. & S.D. & sec. & S.D. & sec. & S.D. & sec. & S.D. & sec. & S.D. \\
\hline 0 & C & $\begin{array}{l}12 \cdot 0 \\
21 \cdot 4\end{array}$ & $5 \cdot 7$ & $29 \cdot 6$ & $\begin{array}{l}6.5 \\
1.7\end{array}$ & $\begin{array}{l}69 \\
69\end{array}$ & $\begin{array}{l}5 \cdot 8 \\
4 \cdot 1\end{array}$ & $\begin{array}{l}12 \cdot 1 \\
10 \cdot 2\end{array}$ & $\begin{array}{l}4 \cdot 2 \\
2 \cdot 6\end{array}$ & $\begin{array}{l}16 \cdot 1 \\
18 \cdot 5\end{array}$ & $\begin{array}{l}1.2 \\
1.2\end{array}$ & $\begin{array}{l}14 \cdot 6 \\
16 \cdot 3\end{array}$ & $\begin{array}{l}1.1 \\
1.3\end{array}$ & $\begin{array}{l}13 \cdot 8 \\
14 \cdot 0\end{array}$ & $\begin{array}{l}0.8 \\
0.9\end{array}$ \\
\hline 1 & $\stackrel{\mathrm{D}}{\mathrm{C}}$ & $\begin{array}{l}12 \cdot 0 \\
16.0\end{array}$ & $\overline{1.75}$ & $\begin{array}{l}24 \cdot 5 \\
22 \cdot 6\end{array}$ & $\begin{array}{l}3.6 \\
1.6\end{array}$ & $\begin{array}{l}64 \\
65\end{array}$ & $\begin{array}{l}2 \cdot 4 \\
2.9\end{array}$ & $\begin{array}{l}9 \cdot 0 \\
9 \cdot 0\end{array}$ & $\begin{array}{l}2 \cdot 4 \\
2 \cdot 2\end{array}$ & $\begin{array}{l}16.7 \\
18.7\end{array}$ & $\begin{array}{l}1 \cdot 3 \\
1 \cdot 7\end{array}$ & $\begin{array}{l}14 \cdot 8 \\
16 \cdot 0\end{array}$ & $\begin{array}{l}1 \cdot 0 \\
1 \cdot 1\end{array}$ & $\begin{array}{l}13.9 \\
14.9\end{array}$ & $\begin{array}{l}1.0 \\
0.7\end{array}$ \\
\hline 2 & D & $\begin{array}{l}12 \cdot 0 \\
14 \cdot 6\end{array}$ & $\overline{1.5}$ & $\begin{array}{l}22 \cdot 3 \\
19 \cdot 7\end{array}$ & $\begin{array}{l}2.7 \\
1.3\end{array}$ & $\begin{array}{l}67 \cdot 7 \\
69\end{array}$ & $\begin{array}{l}4 \cdot 3 \\
3 \cdot 1\end{array}$ & $\begin{array}{r}8 \cdot 4 \\
10 \cdot 9\end{array}$ & $\begin{array}{l}1 \cdot 8 \\
3 \cdot 0\end{array}$ & $\begin{array}{l}16 \cdot 6 \\
18.8\end{array}$ & $\begin{array}{l}1.8 \\
1.0\end{array}$ & $\begin{array}{l}15 \\
16 \cdot 2\end{array}$ & $\begin{array}{l}1.7 \\
0.9\end{array}$ & $\begin{array}{l}13 \cdot 8 \\
15\end{array}$ & $\begin{array}{l}1.5 \\
0.6\end{array}$ \\
\hline 3 & D & $\begin{array}{l}12 \cdot 0 \\
12.9\end{array}$ & $\overline{0.4}$ & $\begin{array}{l}21 \cdot 3 \\
20 \cdot 5\end{array}$ & $\begin{array}{l}2 \cdot 0 \\
2 \cdot 2\end{array}$ & $\begin{array}{l}62 \cdot 6 \\
67\end{array}$ & $\begin{array}{l}3.9 \\
1.7\end{array}$ & $\begin{array}{l}6.7 \\
8.5\end{array}$ & $\frac{1 \cdot 6}{4}$ & $\begin{array}{l}16 \cdot 8 \\
17 \cdot 4\end{array}$ & $\begin{array}{l}1.5 \\
1.6\end{array}$ & $\begin{array}{l}15 \cdot 3 \\
15 \cdot 5\end{array}$ & $\begin{array}{l}1.3 \\
0.8\end{array}$ & $\begin{array}{l}14 \cdot 3 \\
14 \cdot 5\end{array}$ & $\begin{array}{l}1.1 \\
1.0\end{array}$ \\
\hline 4 & $\stackrel{\mathbf{D}}{\mathbf{C}}$ & $\begin{array}{l}12 \cdot 0 \\
13 \cdot 4\end{array}$ & $\overline{2 \cdot 6}$ & $\begin{array}{l}21 \\
19 \cdot 4\end{array}$ & $\begin{array}{l}3 \cdot 0 \\
1 \cdot 2\end{array}$ & $\begin{array}{l}62 \cdot 6 \\
66 \cdot 8\end{array}$ & $\begin{array}{l}2 \cdot 6 \\
5 \cdot 3\end{array}$ & $\begin{array}{c}8 \\
10 \cdot 8\end{array}$ & $\begin{array}{l}1.8 \\
2.9\end{array}$ & $\begin{array}{l}17.4 \\
18.1\end{array}$ & $\begin{array}{l}1.8 \\
1.0\end{array}$ & $\begin{array}{l}15 \cdot 4 \\
16\end{array}$ & $\begin{array}{l}1.0 \\
0.4\end{array}$ & $\begin{array}{l}14.0 \\
15.2\end{array}$ & $\begin{array}{l}1.0 \\
0.8\end{array}$ \\
\hline 5 & $\stackrel{\mathbf{D}}{\mathbf{C}}$ & $\begin{array}{l}12 \cdot 0 \\
12.0\end{array}$ & $\overline{-}$ & $\begin{array}{l}20 \cdot 5 \\
20 \cdot 5\end{array}$ & $\begin{array}{l}1.2 \\
1.8\end{array}$ & $\begin{array}{l}64 \\
66.7\end{array}$ & $\begin{array}{l}3.6 \\
6.6\end{array}$ & $\begin{array}{r}8.4 \\
10.6\end{array}$ & $\begin{array}{l}2 \cdot 1 \\
2 \cdot 5\end{array}$ & $\begin{array}{l}17.7 \\
19\end{array}$ & $\begin{array}{l}1.1 \\
1.1\end{array}$ & $\begin{array}{l}16 \cdot 3 \\
16.6\end{array}$ & $\begin{array}{l}1.2 \\
0.6\end{array}$ & $\begin{array}{l}15 \cdot 3 \\
16\end{array}$ & $\begin{array}{l}0.3 \\
0.5\end{array}$ \\
\hline
\end{tabular}


Although the prothrombin activity was lowered, the other coagulation results were not appreciably different one week after the start of the regime of gradual withdrawal. The increase of Factor VIII concentration was still significant but less marked at the end of the second week.

By the third week of the withdrawal regime the prolongation of the prothrombin time was no longer significant, although the Factor VII level was still reduced (see Chart). By this time the increase of Factor VIII concentration had also disappeared. Unlike the previous " rebound" study, where the cephalin time was dramatically shortened a week after treatment was completely stopped, in this investigation the results at the same stage were not significantly different from the parallel normals. Only when the cephalin-time results were compared with the larger group of 80 normals did the shortening achieve the level of significance.

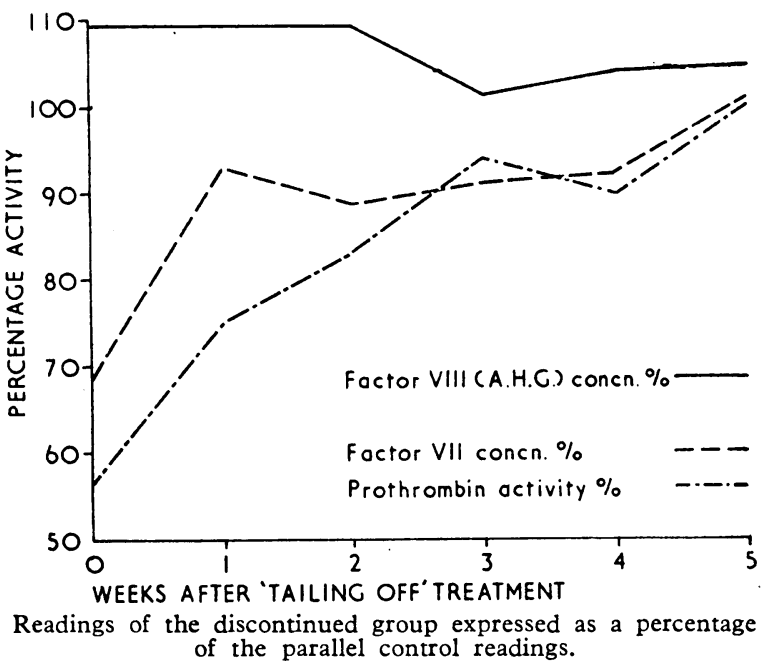

There was no evidence of rebound hypercoagulability in the extrinsic blood-coagulation system.

\section{Discussion}

The present regime of gradual withdrawal of anticoagulants appears to have eliminated the rebound hypercoagulability in the extrinsic (tissue) coagulation system and prevented dramatic changes in the intrinsic system found in the previous study. The striking feature of the previous study had been the reduction in cephalin times at the end of the first week after abrupt withdrawal of treatment. This was associated with an unsuspected increase in the concentration of Factor VIII which we found was present at the end of a period of long-term anticoagulant therapy. This increase of Factor VIII persisted for at least two weeks after stopping full-dosage anticoagulant treatment.

In this investigation, towards the end of their period of the "tailing off" regime, the discontinued group showed less dramatic shortening of their cephalin times, which persisted until one week after the treatment was completely stopped. The clinical importance of the later less-marked " rebound" hypercoagulability found in the cephalin-time tests with the regime of gradual withdrawal is uncertain. The results do suggest that, although the main danger of " rebound" hypercoagulability has been considerably reduced, the regime should be further modified to provide an even more gradual scheme of withdrawal of oral anticoagulant treatment.

\section{Summary}

A study has been made of the effect of a regime of gradual withdrawal of oral anticoagulant on "rebound" hypercoagulability. The regime entailed the "tailing off" of anticoagulant dosage over a four-week period in patients who had been on long-term anticoagulants for an average of 14 months.

The results of coagulation studies suggest that, although the main danger of "rebound" hypercoagulability has been considerably reduced, the regime should be further modified to provide an even more gradual withdrawal of anticoagulant treatment.

A grant for thrombosis research from Manchester Regional Hospital Board is gratefully acknowledged. We are grateful to Dr. M. C. G. Israels for the donation of haemophilic plasma used in the assays.

\section{REFERENCE}

Poller, L., and Thomson, J. (1964). Lancet, 2, 62.

\title{
Frequency of Haemoglobin S and Glucose-6-Phosphate Dehydrogenase Deficiency in Southern Tanzania
}

\author{
H. R. MARTI,* M.D. ; K. SCHOEPF, $†$ M.D. ; O. R. GSELL,* M.D.
}

Brit. med. F., 1965, 1, 1476-1477

A series of 1,232 blood samples were examined in the Ulanga district of Tanzania during July and August 1964 . The survey was carried out in Ifakara, a town in the Kilombero Valley at $780 \mathrm{ft}$. ( $238 \mathrm{~m}$.) above sea-level, with a high incidence of malaria throughout the year. We compared 404 inhabitants of Ifakara with 173 persons living in the highland of Mahenge and other areas of approximately 3,300 ft. $(1,005 \mathrm{~m}$.) altitude with a lower incidence of malaria (transmission rate during less than six months of the year (Atlas, 1948)).

\footnotetext{
- Out-patient Department of Internal Medicine, University of Basle, Switzerland.

† St. Francis Hospital, Ifakara, Tanzania.
}

Of the 1,232 blood samples, 878 were taken from outpatients, 149 from in-patients of the St. Francis Hospital, Ifakara, and 205 from pupils and students of the Upper Primary School, the Girls' Middle School, and the Rural Aid Centre, Ifakara. Of the subjects examined, 1,198 belonged to local Bantu tribes, 8 were Masai, and 26 were citizens of other parts of Tanzania or of the surrounding countries. All 1,232 persons examined (458 males and 774 females) were either adults or children estimated to be 12 years of age and older. The origin of the 1,232 persons was as follows: 404 were inhabitants of Ifakara, 629 were living in other towns or 